\title{
PRESSURE VESSEL AND PIPING CODES APPLICABLE TO THE PWR REACTOR PLANT
}

CONTRACT AT-11-1-GEN-14

BETTIS PLANT

PITTSBURGH, PENNSYLVANIA

Operated for the

U.S. ATOMIC ENERGY COMMISSION bY WESTINGHOUSE

ELECTRIC CORPORATION 
UNCIASSTFIED

PRESSURE VESSEL AND PIPING CODES

APFLICABLE TO THE PWR REACTOR PLANT
WAFD- $\mathrm{FWR}-974$

Reactors - Power

(TID-4500, 13 th Edition)

J. F. Dobinsky

M. B. Andrew

T. R. Moffette

May 1957

Contract AT-II-I-GiN-IL

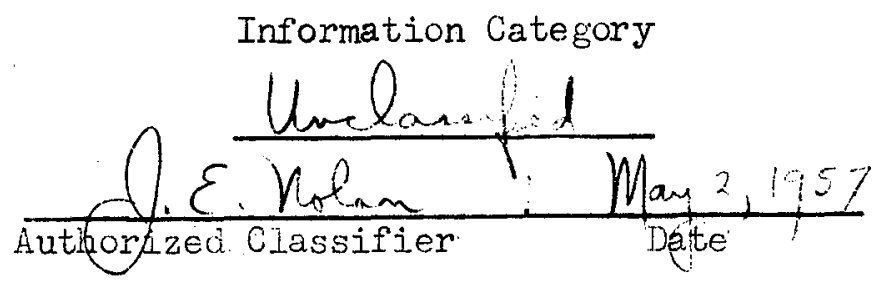

50

Frinted in USA. Price 20 cents. Available from the Office of Technical Services, Department of Cormerce, Washington 25, D.C.

BETTIS FLANT

PITTSBURGH, PA.

Operated for the U. S. Atomic Energy Commission by Westinghouse Electric Corporation

This document is

UNCLASSIFIED

PUBLICLY RELEASABLE

haviace prilliams

Authorizing Official

Date: $08 / 01 / 2007$ 
WA FD- PNR-974

FOREWARD

This document has been submitted to the Advisory Committee on Reactor Safeguards to the Atomic Energy Commission for use in evaluating the safety of the FWR Reactor Plant (Shippingport Atomic Power Station). As such, this information is supplemental to the PWR Hazards Summary Report, WAPD-SC-541.

This report was prepared as an account of Government sponsored work. Neither the United States, nor the Commission, nor any person acting on behalf of the Commission:

A. Makes any warranty or representation, express or implied, with respect to the accuracy, completeness, or usefulness of the information contained in this report, or that the use of any information, apparatus, method, or process disclosed in this report may not infringe privately owned rights; or

B. Assumes any liabilitjes with respect to the use of, or for damages resulting from the use of any information, apparatus, method, or process disclosed in this report.

As used in the above, "person acting on behalf of the Commission" includes any employee or contractor of the Commission to the extent that such employee or contractor prepares, handles or distributes, or provides access to, any information pursuant to his employment or contract with the Commission. 
Aberdeen Proving Ground

$\Lambda$ Ico Froducts, Inc.

Argonne National Iaboratory

Armed Forces Special Weapon Project, Washington

Armed Services Technical Information Agency, Dayton

Atlantic Fleet

Atomic Energy Commission, Patent Branch

Atomic Enorgy Commission, Technical Library

Atomics International.

Battelle Meinorial Institute

Bettis Plant

Brookhaven National Laboratory

Brush Berylitum Company

Bureau of Medicine and Surgery

Bureau of Ships (Code 590)

Chicago Patent Group

Combustion Engineering, Inc.

Consolidated Vultee Aircraft Corporation

Convair-General Dynamics

Defence Research Member

Department of Food Technology (MIT)

Department of Navy (Code 422 )

Department of the Army, G-2

Division of Raw Materials, Denver

Dow Chemical Company (Rocky Flats)

Du Pont de Nemours and Company, Aiken

Du Pont de Nemours and Company, Wilmington

Frankford Arsena 1

General Electric Company (ANPP)

General Electric Company, Richland

General Nuclear Engineering Corporation

Iowa State College

Kirtland $\Lambda$ ir Force Base

Knolls Atomic Power Laboratory

Lockheed Aircraft Corporation (Bauer);

Los Alamos Scientific Iaboratory.

Mallinckrodt Chemical Works

Massachusetts Institute of. Technology (Dr. Hardy)

Mound Laboratory

National Advisory Committee for Aeronautics, Cleveland

National Bureau of Standards, Atomic Energy Project

National Bureau of Standards (Library)

National Lead Company, Inc., Winchester

Naval Research Iaboratory

New York Operations Office .

New York University (Dr. Richtmyer)

Nuclear Development Corporation of America

Nuclear Metals, Inc.

Oak Ridge Institute of Nuclear Studies.

Oak Ridge National Iaboratory

Office of Naval Research 
Distribution .

Millips Petroleum Company

Public Health Service

KAND Corporation

Sandia Corporation

Signal Corps Center

Sylvania Fiectric Products, Inc.

Technical Operations, Incorporated

Union Carbido Nuclear Company (K-25. Plant)

United Aircraft Corporation

U. S. Geological Survey, Denver

U. S. Naval Ordnance Laboratory

U. S. Naval Postgraduate School

U. S. Naval Radiological Defense Laboratory

U. S. Fatent Office

University of California Radiation Latoratory, Berkeley

University of California Radiation Laboratory, Livermore

University of Rochester, Atomic Energy Froject.

University of Rochester (Dr. Marshak)

Vitro Engineering Division

Walter Reed Army Medical Center

Watertown Arsenal.

Weil, Dr. George I.

Westinghouse Electric Corporation

Technical Information Service Extension, Oak Ridge

office of Technical Services, Washington

Manager, Pittsburgh Area Office

WA FD Distributicn XIV
No. of Copies

6
2
1
1
1
1
2
2
3
1
2
1
1
1
2
2
1
2
1
1
1
1
2
300
100
29
70


WA PD-PWR-974

TABLE OF CONTENTS

$\underline{\text { Page }}$

I. ASME CODE AND STATE GOVERNMENT REGULATIONS $\ldots \ldots \ldots \ldots \ldots \ldots \ldots \ldots$

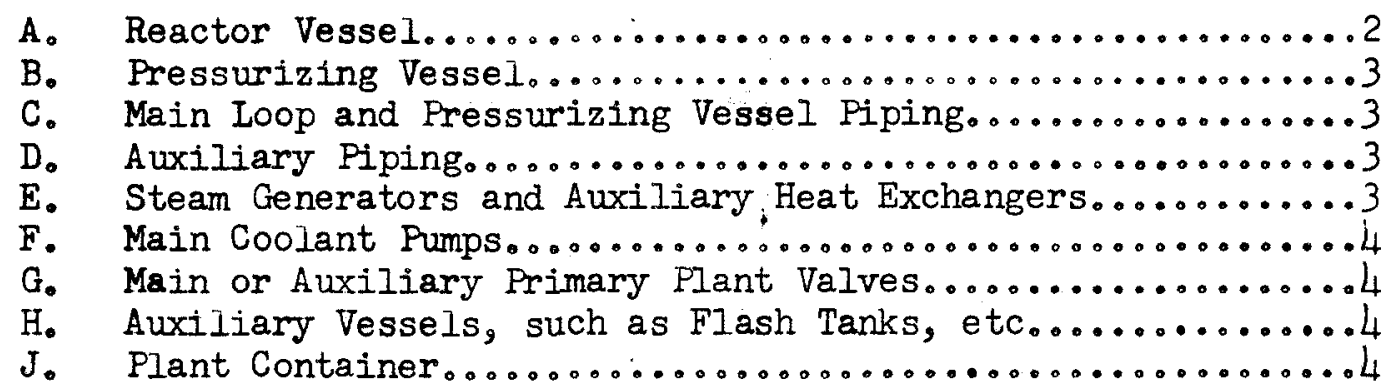

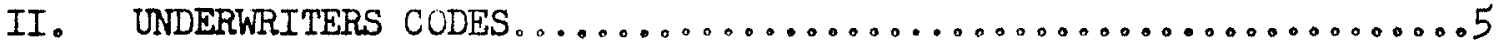

III. MAJOR CODE EXCEPTIONS AND INTERPRETATIONS $\ldots \ldots \ldots \ldots \ldots \ldots \ldots \ldots$

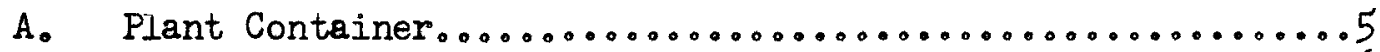

B. Steam Safety Relief Valves.......................6

C. Primary Coolant Relief Valves......................66

IV. ASME BOILER AND PRESSURE VESSEL COMMITTEE SPECIAL RULINGS.....9 
WA PD- FWR-974

PRESSURE VESSEL AND PIPING CODES

APFLICABLE TO THE PWR REACTOR PIANT

J. F. Dobinsky, M。 Bo Andrew, T. R. Moffette

I. ASME CODE AND STATE GOVERNMENT REGUIA TIONS

The policy of the Atomic Energy Commission (AEC), relative to following State codes and regulations in the design of the FWR plant, is extracted from a letter of August. 10, 1954, by the Manager of the Pittsburgh Area Office (PAO) of the AEC to the Manager of the Westinghouse Bettis Plant, as follows:

"As a matter of general policy, for that portion of the plant which will be property of the Government and for Duquesne Light Co. property within the reactor area and located on land leased to the Government by Duquesne Light, State codes should be observed where material and equipment are of such a nature that provisions of existing codes are obviously applicable. For those items and facilities. which are not defined under existing codes, every effort will be made to comply with those provisions which are most applicable, but interpretation in these instances shall remain a function of the Government. If, in the above cases, it appears that compliance with the State code will result in an increase in the over-all cost of the project above that set forth in the approved cost estimate, reference should be made to this office. Observation and compliance as used in the foregoing shall not be construed to mean that certification by the State is a necessary corollary, but certification is desirable wherever practicable.

"With respect to radiation exposure and disposal of waste, either industrial or radioactive, State regulations, where and if existing; shall be observed unless standards of the AEC are more stringent. In this case, the latter requirements shall be applicable."

The question of applicable codes has been resolved for that portion of the FWR plant which is non-conventional, namely the reactor plant container and components within the container.

The Department of Labor and Industry, Division of Boilers of the Commonwealth of Pennsylvania, has jurisdiction over power plant vessels installed for use in the Commonwealth. 
WA PD-PWR-97.4

The Department has adopted the privision of:

(a) The ASME Boiler and Pressure Vessel Code, Sec. I, 1952 edition, with litest published supplements, for its reprint of the Pennsylvania Rules fir. Construction of Power Boilers.

(b) The ASME Boiler and Pressur: Vessel Code, Sec. VIII, 1952 Edition, with latest piblished supplements, in the Pennsylvania Regulation; for Unfired Pressure Vessels, 1954 Edition.

Since the State recognizes the alove ASME Codes, the State will. accept vessels constructed by qualified veldors and stamped with National Board numbers without any special administ ative procedure or review by the Industrial Board of the Department of Labc and Industry. Qualified vendors are those who have valid certificates of thorization for use of code symbols from the ASME Code Committee and are recofized and registered by the State of Pennsylvania. Such qualified vendors have an existing system for transmittal of necessary inspection reports to the ASMI and state agencies and do so as a matter of record.

Where the ASME Code is mentioned below, equal applicability of and conformance to the respective state regulaijions are implied.

If vessels or components are de igned or constructed with any "exceptions" to the above codes, a "Penns, Ivania Special" classification for that vessel can be obtained by petitioning the Industrial Board of the Department of Labor and Industry for such a classification. It was felt that "Pennsylvania Special" coded vessels in the PWR plant should be kept to a minimum because to the uninformed laymen' view, such a vessel might be construed as unsafe. Further, such vesse.s might be ruled unacceptable and might need some modification prior to acc ptance, which could prove costly.

A study showed that all compone its governed by the above codes could be built as standard ASME codes vessels w.th the exception of the plant container and safety devices and appurtenances.

Meetings were held at Harriskrg with Mr. Blaine Book, Chief, Division of Boilers, with representatives of the AEC, Westinghouse and cognizant vendors, to resolve code classificatiors for the components. The following decisions have been reached:

\section{A. Reactor Vessel}

This vessel contains a heat source and is therefore designed and constructed in accordance with the ASMI Code, Sec. I, and will be stamped with an ASME Code symbol and number. 
WA FD-FWR-974

The jurisdiction of the Code for this vessel includes the primary piping (15 in. ID) up to and including the first stop valves, all connecting piping, except instrument piping up to and including the first stop valve, and the penetrations in the vessel head.

\section{B. Pressurizing Vessel}

This vesse I also contains a heat source (electrical heating elements) and is similarly designed and constructed in accordance with the ASME Code, Sec. I, together with the connecting piping up to the first stop valves.

\section{Main Loop and Pressurizing Vessel Piping}

All the main loop piping, the pressurizer piping, and the pipe connected thereto up to and including the first stop valves are designed and constructed in accordance with the ASME Code, Sec. Io Though the jurisdiction of Sec. I does not extend beyond the first stop valve of the connecting piping, all the main loop piping is of identical quality and the entire loops will be given Code (Sec。I) stamping。

\section{Auxiliary Piping}

Piping connected to vessels which conform to the ASME Code, Sec. VIII, will likewise be designed and constructed in accordance with this Section, except that jurisdiction of the Code will extend up to and including the first stop valve as required by the State Regulations for Unfired Pressure Vessels (as compared with ASME Code, Sec. VIII which covers the piping only up to the first joint).

Piping specifications under which the plant is built require that all piping in the plant other than the conforming to the ASME Code as described above shall conform to the American Standard Code for Pressure Piping, ASA B31.1-1955. However, no dual standard was employed as to quality of material or workmanship in the piping within or outside the jurisdiction of the Code. AII pipe materials, both stainless and carbon steels, are those approved by the ASME Code. Inspection of the high pressure pipe welds is more extensive than required by the Code and consists of radiography and dye penetrant checking of the stainless steel pipe butt welds and penetrant checks of socket welded joints. In the higher pressure carbon steel piping, all butt welded joints are radiographed and in those carrying radioactive fluids in the socket welded sizes ( 2 in. and smaller) the welds are penetrant or magnetic particle checked on a random $20 \%$ selection basis.

\section{E. Steam Generators and Auxiliary Heat Exchangers}

These vessels have been designed and constructed in accordance with the ASME Code, Sec. VIII. While Sec. VIII of the ASME Code covers the piping from 
the vessel up to the first circumferential joint for welding end connections, the Pennsylvaria Regulations for Unfired Fressure Vessels covers the piping from the vessel up to and including the first stop valve. The main steam and boiler feed lines are accordingly constructed in compliance with these regulations. The sections of the steam generators and the auxiliary heat exchangers as delivered to the Site have ASME Code Sec. VIII stamping.

\section{F: Main Coolant Pumps}

The outermost pressure containing pârts of the pumps were designed using as a guide the limits of the ASME Code, Sec. VIII. The materials used were recognized by the ASME Code. Welding and weld design were in accordance with the requirements of $\mathrm{ASME}$ Code, Sec. I, and as supplemented by Westinghouse process specifications。

\section{G. Main or Auxiliary Primary Flant Valves}

(1) Safety Valves. Due to the unique heat source in this system, the applicable requirements of Sec. I, regarding safety valves and appurtenances could not be met, since they were written for a conventionally fired boiler that was readily accessible for inspection, maintenance and repair.

The safety intent of the above code was followed.

Specific waivers have been requested from the Industrial Board on the main steam lines and the primary coolant relief valves and have been approved by that agency. These are discussed in detail later in this report.

(2) Main Coolant and Other Valves. These valves were designed and constructed to meet the requirements of ASME Code, Sec. I, P-299 to P-318 and ASA B-16.5, 1953 Edition, Steel Pipe Flanges and Flanged Fittings. Welding was done in accordance with the requirements set forth in ASME Code; Sec. VIII, as supplemented by Westinghouse process specifications.

H. Auxiliary Vessels, such as Flash Tanks, etc.

These vessels were designed and constructed in accordance with ASME Code, Sec. VIII.

\section{J. Plant Container}

This vessel was designed and constructed in accordance with ASME Code, Sec.VIII, 1952 Edition, and Pennsylvania Regulations for Unfired Pressure Vessels, 1954 Edition, with certain "exceptions." The "exceptions" were required due to unique characteristics of this vessel. However, it is desirable for this vessel to be built to code to insure structural and functional adequacy. The Industrial Board of the Department of Labor and Industry was petitioned for "Pennsylvania Special" classification for this vessel, wherein the exceptions were listed. The Board accepted the petition and the vessel was 
WA FD-PWR-974

stamped upon completion, "Pennsylvania Special P.V. No. 1671." The exceptions taken are discussed in some detail later in this report.

II. UNDERWRITER CODES

Since this project is a Government installation, that portion of the plant located in the plant container is not insured by a private insurance company. This portion of the plant has been designed and constructed in accordance with recognized codes, however, so that the plant may be underwritten by insurance concerns at some future date if desired.

III. MAJOR CODE EXCEPTIONS AND INTERPRETA TIONS

As noted above, the major exceptions and interpretations have been concerned with:

\section{A. Plant Container}

A petition, document WAPD $-A D(M)-2925$, dated February 7, 1955, Subj: Petition for Pennsylvania Special Classification on $R_{0} V_{0}$ Container for PNR was sent to the Industrial Board of the Department of Labor and Industry. The petition requested the container be classified as a "Pennsylvania Special" vessel. The vessel was designed to Pennsylvania Code with two exceptions listed below. (However, subsequent ASIVE "Special Rulings" No. 1226 and No. 1235, discussed in detail later in this report, permit the following two "exceptions" to fall within the ASME Code. Current state Code is based on the 1952 edition of the ASME Code, as mentioned previously, and does not yet incorporate these "Special Rulings".)

(1) Subsection B, Sec. UW-2 (a), ASME Code, Sec. VIII

This section states in effect, that all vessels that are to contain lethal substances, when fabricated of low-alloy or carbon steel shall be stress relieved. Thermal stress relief is impractical due to the large size of the containers.

(2) Subsection A, Sec.UG-I25 (a) ASME Code, Sec. VIII

This section states in part: All unfired pressure vessels within the scope of this code irrespective of size or pressure, shall be provided with protective devices in accordance with the requirement of UG-125 through UG-134. The basic reason for providing containers is to prevent escape of toxic gases or radioactive material into the atmosphere. The presence of code relief valves set at design pressure would nullify the function of the containers.

Approval was received in a Department of Labor and Industry letter, dated March 22, 1955, which authorized the completed container to be stamped

"Pennsylvania Special P.V. No。1671." 
WA PD $-P W R=974$

\section{B. Steam Safety Relief. Valves}

A petition, document WAPD-AD(MM)-3016, dated March 15, 1955 requested waivers on requirements of ASME Code, Sec. I on the se valves. Approval was granted in a Department of Labor and Industry letter dated June $27,1955$.

\section{Primary Coolant Relief Valves}

A petition, document WAPD-AD(MM) - 3339, dated August 8 , 1955, requested waivers on the relief valves, appurtenances such as gage cocks and sight glasses, etc, as specified in ASNE Code, Sec. I。

The specific waivers required on the main steam iines and the primary coolant relief valves are listed below:

(1) That the use of water relief vaIves in lieu of steam safety relief valves to protect the reactor vessel be allowed since no steam is generated in this vessel.

(2) That the valves be sized to relieve expanding water at a rate which will prevent the maximum pressure from rising more than 6\% above design pressure when the reactor is operating at maximum capability. A method was determined that was applicable for calculating the required valve capacity, since the method of determining relieving capacity as listed in $\mathrm{P}-274$ or $\mathrm{P}-275$ is not applicable to the PWR type of plant.

(3) That the use of balanced (spring-loaded) type safety and relief valves whose capacities and set points are independent of back pressure be allowed. This requirement is essential for the PWR plant sirice the effluent from the valves is radioactive and must be contained and condensed, which, in turn, results in a back pressure on the valves. This requirement is at variance with P-278 and P-279.

(4) That the use of a lifting device, as listed in P-282, not be required. It is undesirable to test these valves during operation of the plant. However, if necessary they can be tested with the plant shut down. The valves will be tested to insure functional, operating and structural adequacy, in a test loop, prior to instaliation in the plant.

(5) That the instaliation of duplicate relief valves (with shutoffs in each discharge iine which are interlocked to prevent closing of both relief paths) be allowed. Past experience has shown unsatisfactory reseating characteristics in some valves which has required reactor shutdown. 
(6) That the location and method of installation of safety relief valves, as listed in P-277 and referenced paragraphs, be waived and that the valves be installed in a cubicle shielded from the vessels they protect for accessibility and maintenance purposes.

(7) That the setting of the relief valve for each loop be allowed to be 2830 psi. The basis for the 2830 psig setting on the loops is that the pressure during isolation would not exceed 120\% of the design values for $1 \%$ of the time as specified in P-23, $f(2)$. It is pointed out that these valves would operate only in an emergency where an external source of heat is applied, or by operation of the charging pump when the $100 \mathrm{p}$ is isolated. The capacity of these valves was not included in the sizing of the relief valves for the two internally heated vessels, the pressurizing tank and the reactor vessel. It is undesirable to set these valves at design pressure, since they would then open at the same time as the main relief valves on the reactor vessel; the main valves have sufficient capacity to relieve the system. These valves are needed only for an isolated loop. If these valves failed to reseat, they could be a source of trouble tending to drain the vessel.

(8) That the set pressure tolerance for all safety valves in the above system be \pm 50 psi. With the use of balanced (spring loaded) type safety and relief valves, \pm 10 psi of set pressure is difficult to meet.

(9) That the "blowdown" requirement, as listed, in P-28I be a maximum of $6 \%$. A maximum of $4 \%$ cannot be met under all conditions since these valves do not have the pop action of conventional safety valves.

A waiver was also requested on the water and steam gages section of ASME Code, Sec. I, P-291 through P-298 and the referenced paragraphs therein, for the following reasons:

(1) Paragraphs 29 I through 296 would require gage glasses and try-cocks on the pressurizer and reactor vessel. These would be useless on the reactor vessel since the vessel is completely filled with water. Although the pressurizer is only partially filled with water, since it cannot be seen by the operator because of shielding and its location in the reactor plant container, this equipment would serve no useful purpose. 
(2) Paragraph 297 specifies: "The dial of the steam gage shaIl be graduated to approximately double the pressure at which the safety valve is set but in no case to less than $1-1 / 2$ times this pressure." There are actually seven instruments in the control room indicating the plant pressure all except one of which meet the requirement of $\mathrm{P}-297$. The pressure signal to each is electrical, with an individual electrical circuit for each. These instruments and their ranges are:

One pressurizer pressure indicator-recorder, controller

One pressurizer pressure indicator

One reactor vessel pressure indicator

Four main loop pressure indicators
Range, psig $1800-2300$

$0-3000$

$0-4000$

$0-4000$

Control of the plant pressure is done by means of the signal to the pressurizer pressure indicator-recorder-controller, which has a range of 1800 to 2300 psig. If this instrument were required to have the range required in $\mathrm{P}-297$, it would reduce the accuracy of the instrument and increase the frequency of operation of the safety valves. Furthermore, in view of the fact that a number of other wide-range instruments meeting the intent of $\mathrm{P}-297$ will be in service, it is believed unnecessary for this instrument to also meet the code requirement.

Approval for these changes was granted in a Department of Labor and Industry letter dated September 19, 1955.

All major components have been reviewed with the Department of Labor and Industry. Specific rulings have been agreed upon with Mr. Blaine Book, Chief, Division of Boilers, and the above rulings are on file in his office.

The necessary petitions are on file with the Secretary of the Industrial Board. 
WAPD-PWR-974

IV. ASME BOILER AND FRESSURE VESSEL COMITTEE SPECIAL RULINGS

The Boiler and Pressure Vessel Comittee of the ASME considers "Cases" where users have difficulty in interpreting the Code. "Committee interpretations are submitted to the ASME Board on Codes and Standards, authorized to pass upon them. The following Case Interpretations were formulated by the Committee, approved by the Board, and reported in Mechanical Engineering. These recent inquiries and rulings are intended for nuclear installations in general, and are of considerable interest with regard to PWR. Although FWR was designed and partially constructed prior to these rulings, the PWR design complies with the new requirements wherever applicable.

Case No. 1224 (Special Ruling) (Mechanical Engineering, Vol. 78, Oct., 1956, p. 969)

"Inquiry: Neither Sec. I nor Sec. VIII of the ASME Boiler and Pressure Vessel Code as now written precisely covers pressure vessels that are an integral part of a nuclear installation. Under what rules shall they be constructed?

Reply: The Committee recognizes that in the design of nuclear installations, requirements will differ from those of conventional boilers and pressure vessels.

1. It is the opinion of the committee that vessels that are an integral part of núclear installations built in accordance with the requirements of the ASME Boiler and Pressure Vessel Code as modified or defined in this and subsequent cases, meet the intent of the Code, and each vessel shall be marked as required by the section to which it is built including the appropriate Code Symbol. In addition, the words, "Case No. " shall appear on the Data Report.

2. All vessels that are an integral part of nuclear installations shall be constructed in accordance either with the requirements of Sec. I or with the requirements of Sec. VIII for vessels that are to contain lethal substances.

3. It is intended that jurisdiction over piping external to vessels shall terminate at:

(I) The first circumferential joint for welding end connections; or,

(2) The face of the first flange in bolted flange connections; or,

(3) The first threaded joint in that type of connection."

Case No. 1224-1 (Reopened)(Special Ruling)(Mechanical Engineering, Vol. 79, April, 1957, po 393)

Add the following as new Item 4 in the Reply: 
WA PD $-P W R-974$

\section{"Definitions:}

The Reactor Vessel is that vessel in which nuclear fuel is present and in which the nuclear chain reaction takes place. Primary Vessels are those vessels, other than the reactor and containment vesse 1 , which contain or may contain reactor coolant. These vessels may be heat-exchangers, pressurizer tanks, drain tanks, dewatering vessels, etc. Secondary vessels are all other vessels which do not contain reactor coclant or are not otherwise subject to irradiation. Secondary vessels are covered in appropriate sections of the Code.

Containment Vesse 1 s are those outer vessels which enclose the reactor. vessel or portions of the primary coolant circuit or both. The containment vessels are not normally pressurized and are built to contain the lethal radioactive substances that may be released in case of an accident or failure of the reactor vessel or the primary coolant circuit or both."

Case No. 1225 (Special Ruling)(Mechanical Engineering, Vol, 78, Oct., 1956, p. 969)

"Inquiry: Various safety requirements of Sec. I and Sec. III would actually be hazardous if applied literally to the design of nuclear reactors. May these requirements be modified for reactors of the pressurized water and boiling water types?

Reply: It is the opinion of the Committee that nuclear reactors of the pressurized-water and boiling-water type will meet the intent of the Code and sha11 be marked in accordance with Case No. 1224 if the following provisions are met:

1. Totaliy enclosed pop-type safety or relief valves shall be provided, but need not be directly attached to the vessel provided there is no valve between the vessel and the safety or relief valve; also they shall be installed as close as is practical to the vessel. They shall not discharge to the atmosphere, and shall discharge to a suitable system designed to condense any vapors. At least two safety or relief valves are required and the total capacity shall be sufficient to insure that the design pressure is not exceeded by more than $10 \%$.

2. Direct reading pressure gages are not required. At least two independent devices for determining pressure are required and these shall not be dependent on the same external sources of energy.

3. Inspection openings, gage glasses, water columns, and gage cocks are not required."

Case No. 1226 (Special Ruling)(Mechanical Engineering, Vol. 78, Oct., 1956, p. 970)

"Inquiry: May containment vessels for nuclear reactor installations be built under Sec. VIII, Code for Unfired Pressure Vessels, without stress relieving as specified in Far. UW-2(a)? 
WA PD-PWR-974

Reply: It is the opinion of the Committee that these containment vessels fall under the category of those containing lethal substances but still may be built without stress relieving provided the following requirements are met:

1. Plates and forgings of containment vessels exposed to the elements (not inside a heated enclosure)* shall conform to specifications SA-300 for plates and SA-350 for forgings. These and other materials and the construction shall meet the impact test requirements of Par. UG-84 at a temperature not less than $30^{\circ} \mathrm{F}$ below the lowest recorded ambient temperature of the area in which the containment vessel is to be erected, except that the lowest test temperature may be assumed to be - 50\% for any part of the United States."

2. Welding procedures and operators shall be qualified in accordance with Sec. IX.

3. All doors, nozzles, and opening frames shall be preassembled into shell plate and stress relieved as complete assemblies for welding into the shell. Also, special consideration should be given to make the design of the reinforcement for large openings as strong as the shell, (see Par. UA-7).

4. The thickness of she 11 and head plates shall not exceed that for which stress relief is required in accordance with Par. UCS-56.

5. All longitudinal and circumferential joints sha $\perp l$ be of the double-welded butt type and shall be fully radiographed in accordance with Par. UW-51. AlI welds on doors, nozzles, and openings frames, and all welds that cannot be radiographed shall be examined for cracks by magnetic particle or fluid penetrant method of inspection.

6. The Case number shall appear in the Manufacturer's Data Report Form".

Case No. 1226-1 (Reopened)(Special Ruling)(Mechanical Engineering, Vol. 78, Dec., 1956, p. 1169)

"In the Reply, revise Par. (4) to read: (4) The thickness of the shell and head plate shall not exceed that for which stress-relieving is required in accordance with Par. UCS-56, except that for materials listed under group P-Number 1 in Table UCS-23, stress-relieving is not required in thicknesses over $1-1 / 2$ in., and up to $1-1 / 2$ in., inclusive, provided a preheat of $200^{\circ} \mathrm{F}$ is used during welding."

* It is considered that paragraph (I) does not apply to PWR since the plant container is enclosed in a concrete box-like structure, and is not exposed directly to the elements. The atmosphere within the concrete enciosure will be continualiy replenished with warmed air forced in from the fuel handing building. Additional heat will be radiated and convected from within the plant container whenever the reactor plant is in operation. Although impact tests were not made, the plates and forgings used as pressure retaining parts do conform to the material requirement of paragraph (I). 
WA PD-PWR-974

Case No. 1226-2\%(Reopened)(Special Ruling)(Mechanical Engineering, Vol。79, Feb., 1957, p. 195)

"In the Reply, revise the definition of Containment Vessels at the end of Case to read as follows:

Containment Vesseis are those outer vessels which enclose the reactor vessel or portions of the primary coolant circuit or both. The containment vessels are not nomally pressurized and are built to contain the lethal radioactive substances that may be released in case of an accident or failure of the reàctor vessel or the primary coolant circuit or both."

Case No. 1226-3 (Reopened)(Special Ruling)(Mechanical Engineering, Vol.79, April, 1957, p. 393)

"Revise the Inquiry as follows:

Inquiry: May containment vessels as defined in Case No. 1224-1* for nuclear reactor installations be built under Section VIII, Code for Unfired Pressure Vessels, without stressorelieving as specified in Par. $\mathrm{UW}-2(\mathrm{a})$ ?

Add to the Reply new subparagraph (7) as follows:

(7) Provisions for corrosion shall be made in accordance with Par. UG-25. The mandatory requirements of Far. UCS-25 are not intended to apply to containment vesseis. :

Case No. 1228 (Special Ruling) (Mechanica」 Engineering, Vo]. 78, Dec., 1956, p. 1169)

"Inquiry: In a two-stage construction of a containment vessel built under Case No. 1226 for a nuclear reactor, will the vessel be acceptable if during the pneumatic test certain of the weIds in the lower part of the vessel are not available for inspection because of concrete shielding or concrete supports placed on inside and outside of the vessel after construction of the lower part?

Reply: It is the opinion of the Committee that containment vessels built under Case No. 1226 for nuclear reactors will meet the intent of the Code when erected in two stages, provided:

1. All inaccessible welds are double-butt welded, radiographed, and fully inspected and tested for leak tightness using a gas medium such as halide leak detector test prior to being covered.

2. All other requirements of the Code are met including a pneumatic test of the completed vessel.

3. Inspection of welded jojnts in the lower part of the vessel during the pneumatic test will be waived where such joints are covered by concrete during the construction of the vessel, provided there are no openings or penetrations of that part of the vessel covered by concrete."

* The revision of Case No. 1226-3 deletes the definition given in Case No. 1226-2. 
WAPD-PWR-974

Case No. 1235 (Interpretation of Pars. UG-125 to UG-134) (Mechanical Engineering, Vol. 79, April, 1957, pp. 393-394)

"Inquiry: May containment vessels for nuclear reactor installations be built in accordance with Section VIII, Code for Unfired Pressure Vessels, without pressure-relief devices as required by Fars. UG-125 to UG-134?

Reply: It is the opinion of the Comittee that, since it is intended that these vessels be designed and built to safely contain all the lethal radioactive substances that may be released in case of a maximum credible accident affecting the reactor vessel or primary coolant circuit or both, and because of the hazardous character of the materials which might be released, pressure relief devices are not required. If for any reason such devices are installed, adequate provisions shall be made for safe disposal of the effluent." 